\title{
Russia's Caucasian Interests Throughout the Centuries and Georgia
}

\author{
Otar Janelidze \\ Faculty of Humanities, Gori State Teaching University, Gori, Georgia \\ Email address: \\ otar_janelidze@yahoo.com

\section{To cite this article:} \\ Otar Janelidze. Russia's Caucasian Interests Throughout the Centuries and Georgia. History Research. Vol. 9, No. 1, 2021 , pp. 12-20. \\ doi: $10.11648 /$ j.history.20210901.12
}

Received: November 23, 2020; Accepted: January 16, 2021; Published: January 22, 2021

\begin{abstract}
The article highlights the interests of the Russian Empire in the Caucasus region. It is emphasized that in the 16th and 17 th centuries the main motives for the expansion of the Russian State in the Caucasus were determined by strategic tasks, but the aspiration to expand to the South of the country was also important. Famous Russian Historians M. Lyubavsky, M. Polyev-ctov and others argued that Russia's interests in the Caucasus and the Caspian were characterized by colonial aspects from the very beginning. Thus, the prevailing view in Russian historiography that leaders of the Russian State were pushed into the Caucasus by purely altruistic reasons, driven by the generous mission of rescuing Christian peoples from violations and religious aggression by the Muslim peoples cannot stand criticism. From the end of the 18th century, the Caucasus issue was closely linked to the Eastern question, which was a major international policy issue. According to Russia's imperial ambition, the Caucasus, as a path to the East, was to become a new springboard for its influence in the Middle East. In the 19th century, the problem of the Caucasus was solved by Russia in its own favor, by exterminating opposing Iran and the Ottomans from the region in successful wars, and gaining dominance in this disputable space. This situation lasted for almost two centuries. The locals considered Russia an aggressor who did not liberate the Caucasus, but conquered it. After a long dominance in the region, the Russian Federation still cannot give up the Caucasus and considers it a zone of "its special interest".
\end{abstract}

Keywords: Russian Empire, The Caucasus, Georgia, War, Conquest

\section{Introduction}

Diplomatic relations between the Russian Federation and Georgia have been severed since the August 2008 war, but the issue of relations between the two countries is still relevant. The interest is conditioned not only by the desire to achieve good neighborly coexistence between Russia and Georgia, but also by the need for an objective understanding of the past and a better understanding of it.

The problem posed in the article is multifaceted. Its historiography is also extensive and heterogeneous. Much of the Russian (1801-1917) and Soviet-era literature devoted to the study of the topic is one-sided, the issue being seen and covered only from a Russian perspective. These papers focused not on the true purpose of imperial expansion, but on the positive manifestations of Russian policy in the lives of conquered and united peoples. The reality was different.

The paper tries to present the issue from different perspectives and in a differentiated way: to outline the expectations of the peoples of Georgia and the Caucasus, which they linked to rapprochement with Russia, and to describe the real consequences of Russia's establishment in the Caucasus. On the other hand, we are trying to show the interest, goals and objectives that Russia has had and has in the region over the centuries.

Russia's Caucasian interests cannot be found in historical sources as a unified concept or an official written document. Various rulers at various points in history utilized specific ways and measures for implementing these interests - be it political, diplomatic, military, trade-economic relations, colonization or other.

Since the beginning of the 19th century, the Russian ruling circles considered Georgia a conquered, colonial possession, but refrained from formally approving this thesis. The formula "voluntarily part of the empire" seemed more respectable. That is why Russian official historiography 
introduced the term "voluntary joining". The act of liquidation of the Kingdom of Kartli-Kakheti is called "voluntary joining" of Eastern Georgia with the Russian Empire in the works of P. Butkov, N. Dubrovin, O. Pottos, P. Berge and other contemporary Russian authors.

Some Russian authors still repeat that the peoples of the Caucasus themselves provoked Russia's violent action in the region. That an external threat from the Caucasus pushed the Russian authorities to take precautionary measures to protect the country's territorial integrity and state independence.

The reasons for the war for the conquest of the Caucasus are also obscured in Russian historiography. They write that the war was caused by the predatory and disobedient nature of the mountaineers and the necessity of their subjugation. Or again, as if this forced war was triggered by the protection of monotheistic Christians (V. Kluczewski, A. Zajonckowski) and nothing is said to have been the fruit of imperial politics.

Soviet historical science (M. Pokrovsky, R. Magomedov, etc.) initially emphasized the anti-feudal and anti-colonial nature of the mountain struggle, considered it a liberating, progressive movement, but by the middle of the twentieth century, the approach to the problem had changed slightly., As the movement of the mountaineers of the North Caucasus against the colonial policy of tsarism and the oppression of local feudal lords. As for modern studies, they are mainly characterized by a pluralistic approach to the issue.

\section{Method}

The article examines and discusses Russia's attitude towards the Caucasus region over the centuries.

The research is based on the method of historicalcomparative, retrospective and content analysis, as well as critical comprehension and generalization of empirical material, presenting the issue from different angles.

\section{Discussions}

Russia has always lived for conquests and annexing new lands I. Afanasyev Russia's imperial gaze crossed the Caucasus ridge in the last quarter of the $15^{\text {th }}$ century. The Caucasian aspirations of the representatives of this state were apparent long before they took on a character of clear geostrategic interests. According to historian and Russian Army General, V. Potto, starting from Ivan IV, almost all Russian rulers were trying to establish their power over the Caucasus and "the thoughts of ruling over the Caucasus become hereditary in Russian history [26]. Russia, which had declared itself a successor of the Byzantine Empire, first appeared in the South Caucasus region during the rule of Ivan III (1462-1505), establishing contacts with the Kingdom of Kakheti. These relations did not surpass the level of exchanging ambassadors which served as a type of reconnaissance.

In the middle of the $16^{\text {th }}$ century, after Ivan the Terrible had annexed the territories around the Volga River (Privolzhsky) and Kabardo, Moscow was no longer hiding the fact that it was interested in having a "dependent ally" in the Caucasus region. According to academician Niko Berdzenishvili, the historical situation "brought together the foreign policy interests of Muscovite Russia moving towards the southeast and the Kingdom of Kakheti which was encircled by enemies" [3]. From then on, Russia became actively involved in the Iranian-Ottoman struggle taking place in the region which meant tooth-and-nail confrontation with both of these powers.

The famous Russian scholar of the Caucasus, R. Fadeev, wrote in his 1860 book that occupying the Caucasus was due to a "primary state necessity" [12].

The difficult local military-political situation, the constant involvement of the Caucasus in wars and conflicts, the existence of mobile military formations hostile to Russia in the region, the lack of natural barriers protecting Russia's southern borders and the need to break the trade and economic blockade and open a window to Asia required stability and ensuring the defensibility of the state in this direction. Therefore, the main motives of the expansion of the Russian state in the Caucasus in the $17^{\text {th }}-18^{\text {th }}$ centuries were determined by defense and military security considerations which owing to their strategic goals. The fate of the peoples of the Caucasus and their armed defense was the cornerstone of Russia's Caucasus policy for a long time [5].

In the same period of time, Russia's major interest vis-àvis the Caucasus can be considered to be an expansion towards the south. In Russia's imperial ambitions, the Caucasus would be a path to the East in not-so-distant future as well as becoming a base of operations for establishing Russia's influence over the Middle East and, after this, even India did not seem too far of a reach.

The geopolitical importance of the South Caucasus was mainly determined by its naval and land-based communication systems with European and Asian states as well as its trade transit function between the West and the East. This region, which is not very large in terms of its territory, represented a good strategic base in every historical era for which both neighboring, as well as far-away conquerors, fought each other with rigor.

Russian history as well as Soviet historiography assesses Russia's constant attraction towards the Caucasus in a biased manner. The view is that representatives of the Russian state and politicians only had altruistic motives for entering Caucasus. Imperial Russia was supposedly compelled by the noble desire of freeing peoples of a common religious faith from violence and religious oppression on the part of Muslim aggressors. "The central idea here is of total charity: saving the people of a common faith, providing well-being and education to them. It was doing the Christian duty. Actions in the South Caucasus and the Caucasus in general were the new crusades" [7], says Russian historian, writer and publicist, I. Gordin.

This view is based on the messianic idea originating from the $16^{\text {th }}$ century formulated in the following manner: "Moscow is the third Rome." According to this concept, 
Russia, as a successor of the Roman and the Byzantine Empires, has a special "divine mission" in the world. The defining axis of this imperial idea was the ideology of the Christian brotherhood as well as saving and protecting the people of the Orthodox Christian faith. The Russian Tsar, as a King of all Christian people, was supposed to fulfill the function of uniting the Christian people of the world, saving the oppressed Orthodox Christian brethren, freeing them and protecting them [28].

There is also another view such as, for example, that of the famous Russian historian, N. Kostomarov. In Peter I's aspiration of extending the boundaries of the Empire and obtaining a suitable place for it among the European states, he saw, on the one hand, the desire to turn Russia into a naval state while, on the other hand, he pointed out that Peter was interested in bringing the light of European civilization coming from the West to the Eastern peoples who were on a lower level of cultural development as compared to Russia [22].

Russia was indeed facing a pressing issue of gaining access to warm southern seas. Of special importance was obtaining control of the Black Sea, the Bosporus Straits and the Dardanelles and entering the Mediterranean Sea which was considered to be a prerequisite for gaining a foothold in the Middle East and then moving towards India. As for transferring Western civilization to the East through Russia, especially in the era of Peter I, this is a clear exaggeration and not worth our attention at the moment.

Today, Russian historiography shares the view that Russia's interests became expansionist only after it achieved the status of an empire (1721) [4;8]. The view of an academician, A. Arbatov, seems to be more precise that Russia has always been a military-political empire. It acquired colonies for ensuring its security and increasing its political and military might and role throughout the world [31]. According to contemporary Russian historian, E. Anisimov, "Russia's specific nature is that it has been an empire almost from the very beginning" [2].

The main defining feature of Russian colonialism was expanding the boundaries of the empire at the expense of its neighboring territories. Russia conducted wars of conquest, integrated new lands, became more powerful and put more and more territories and peoples within its orbit. The process of integrating new lands, which went on for several centuries, was called "собирание земель" or “расширение границ" or “активная внешняя политика" [gathering lands, extending borders, active foreign policy] at different points in history, yet it was never called what it actually was - expansion. It was precisely the large-scale territorial expansion and conquests that constituted Russia's total strategy as well as the main source of state development [14].

A famous Russian historian, I. Afanasyev, points out: "Russia is characterized with constant aggression and expansionism which originates from the time of the rise of Moscow. Russia has always lived for conquests and annexing new lands. There is not even a relatively small period in Russian history without wars: either of conquest or defense.
And they never thought of better developing the already acquired territories, on the contrary - they always thought to conquer as much as possible".

The importance that Russian rulers placed on Georgia and the South Caucasus region is clear from the fact that during Peter I's rule, a special department was formed in St. Petersburg which was tasked with coordinating and deepening relations with kingdoms, principalities and khanates in the South Caucasus. Originally, it was called the Trans-Caucasus Affairs Committee while there was a Caucasus Committee from 1845-1882. It consisted mainly of imperial ministers. The chairmen of these committee at various times were the Military Minister, A. Chernishev; Chief of the Gendarmerie, A. Orlov, and Count P. Ignatiev [23].

It is known that from the second part of the $18^{\text {th }}$ century, Russia was creating and developing plans such as the "Greek Project" or the Treaty of Georgievsk. The Viceroyalty of Caucasus was formed in 1785 which consisted of the districts of the Caucasus and Astrakhan, the Caucasus military line was formed and so on. By completely disregarding these projects, Paul I took an unprecedented step - he altogether abolished the Kingdom of Kartl-Kakheti through a manifesto, declaring Eastern Georgia as part of the Russian Empire with the status of a governorate.

If Russia's prior relations with the Caucasus were "fragmented and episodic" in character, from the middle of the $18^{\text {th }}$ and the beginning of the $19^{\text {th }}$ century the issue of Caucasus became closely linked with the issue of the East in general which was an important problem in international politics. From the same period of time, the militarization of the Russian Empire became all-encompassing. If about a third of the state budget was being spent on army upkeep during Peter I [21], now all state resources were primarily directed towards bolstering military might while increasingly low amounts of funds were allocated for economics, culture and other fields. The example of the Caucasus is also a clear illustration of this: the $17^{\text {th }}$ Jaeger Regiment that entered Eastern Georgia in 1799 became the basis for the formation of the Georgian (Caucasus) corps which, under the Commander-In-Chief, P. Tsitsianov (1803-1806), consisted of seven land regiments and several dragoon squadrons (17,469 soldiers). Under General A. Ermolov (1816-1827), the corps already consisted of 11 regiments which were up to 40,000 strong. The following Commander-In-Chief, Count I. Paskevich (1827-1831), had 57,000 soldiers under his command [4].

According to the testament of a researcher of military history and theory, the exiled Russian General, N. Golovin, the Empire was spending about one-sixth of its enormous revenues on wars in the Caucasus [41]. This is yet another clear indication that the Caucasus region had special political, military and economic importance for Russia.

It is no coincidence that the conquest of the Caucasus became an important theme in $19^{\text {th }}$ century Russian classical literature (the works of A. Pushkin, A. Bestuzhev-Marlinski, I. Lermontov, L. Tolstoy and others) and paintings (G. 
Gagarin, F. Rumbo, N. Chernetsov, V. Vereshchagin) (According to academician, F. Dubrovin, no part of Russia has such an extensive literature in all fields as does the Caucasus [9] I. Gordin's studies about the phenomenon of the Caucasus in the societal and cultural perception of Russia are notable.) which is not true of Central Asia and the Far East that also ended up within the boundaries of the Empire at that time. These territories were covered more widely by the press rather in than literature and fine art. In addition, while the masters of Russian literature highly praised the generals undertaking conquests in the Caucasus, the liberal press even had some criticism towards the aggressive policies of conquest in Central Asia and the Far East [35].

After gaining a foothold in eastern Georgia, the tsarist government actively sought to expand its dominions in the South Caucasus, paving the way for the eastern shores of the Black Sea, where Georgian fortresses still housed Ottoman garrisons. However, one of the priority tasks was to annex or establish influence over the Muslim khanates in the region, which was achieved.

It is known that the $19^{\text {th }}$ century was decisive in the establishment of the perception of the Caucasus: in the first quarter of this century, Eastern and Western Georgia, Eastern Armenia and the territories on the eastern part of the southern slopes of the Greater Caucasus Ridge that were integrated into Russia with this area called the Trans-Caucasus. After the Caucasus joined the Russian Empire, the Russian administration introduced notions such as the Small Caucasus, the Trans-Caucasus and the Caucasus Krai [34].

By incorporating Eastern Georgia into the Empire in 1800, Paul I took the first steps towards appropriating the Caucasus while Alexander I made this process irreversible. According to the saying popular in the late period of his rule - „Stand strong in the Caucasus" - a new formula was created for establishing foothold within the region which was later picked up by the policy of "taming the mountaineers".

When it won the wars with Iran and the Ottomans in the first 20 years of the $19^{\text {th }}$ century, substantially strengthening positions in the Caucasus, the Tsarist government stepped up its attack on the North Caucasus although it faced a prolonged conquest therein. (To this day, historiography does not have a unified position on why the war started or what its length was. The chronological boundaries of the war are unclear and even its name is subject to differing opinions.) Lengthy combat operations of the Russian army in the Caucasus were referred to with terms such as: "покорение," “утверждение,” “завоевание,” “вхождение,” “присоединение,” “включение,” “усмирение,” “умиротворение," “установление русского владычества" [subdual, assertion, conquest, entering, integrating, incorporating, appeasement, pacification, instituting Russian rule]. Russian historians write that war in the North Caucasus was due to the wild, predatory and untamed nature of the mountaineers as well as the necessity of subduing them [20]. Another supposed reason was that the war was caused by the necessity to protect Christians who shared a religious faith with Russia (V. Kliuchevsky, A. Zaionchkovsky), saying nothing about the fact that war was a reflection of Russia's imperial policies.

Russian conquerors did not deny the fact that they were behaving towards the mountaineers in a manner similar to the Spanish conquistadors in the Americas. Dekabrist, A. Rozen, pointed out: „Just like Pizarro and Cortez, we brought only weapons and fear to the Caucasus" [27]. Russia was truly drowning the Caucasus in "blood and tears" (A. Gerzen) as the region was not putting up with and, in fact, "hated Russian domination" (N. Dobrolyubov).

In the first half of the $19^{\text {th }}$ century, the government of Russia saw the North Caucasus as an important strategic region, both in terms of the territorial expansion of the Empire as well as its economic interests [36]. In their works, novels or other publications, famous representatives of Russian literature justified the conquest of the Caucasus, calling it a "heroic endeavor." Some of them personally fought for subduing the mountaineers and incorporating them into the Empire. It is sufficient to name I. Lermontov and L. Tolstoy in this regard as they were officers of the Russian army in the North Caucasus.

Throughout its imperial expansion, Russia had never encountered such an organized resistance from the local population as it did in the North Caucasus [33]. The mountaineers' fight for freedom was led by Kazi-Muhamad (1829-1832), Hamzat-Beg (1832-1834) and Shamil (18341859). (One of the notable leaders of this fight was HajiMurat who originally sided with the Russians; however, in 1840-1851, he joined Shamil and became famous for his bravery and daring.)

Russia and the North Caucasus at the time were two different worlds. Local mountaineers were barely familiar with the essence, opportunities and aspirations of the state that had just moved to conquer them. The Russian legal system was also entirely alien to the Caucasians who lived according to societal customs and traditions. In the Russian Empire, the Caucasian mountaineers only saw an aggressor and a conqueror which was violating and undermining their traditional state of being and their way of life.

Russia, on the other hand, was looking at the Caucasus as a space for conquest which it would later use according to its state interests. It saw good, normal and neighborly relations with the local peoples as almost inadmissible. The government of the Empire knew nothing about the internal logics of the behavior or the fight of the Caucasian mountaineers and was not even interested in learning about it which is why it disregarded the religious and cultural identity of the population of this region and violated and trampled upon their honor and national rights.

The Russian imperial stereotype assessed the resistance offered by the political or ethnic entities selected for conquest as actions of "gangs" and "wild mobs," (That is how the predecessors of contemporary "illegal armed formations" were being branded.) confronting them with the most violent of methods and forceful measures. Furthermore, they saw the local population as people at lower stages of development whose fate was to be controlled by the Empire. The imperial 
government believed any types of concessions to be a demonstration of weakness which is why their expansion in the valleys of the Caucasus Mountains were characterized by boundless violence. The local population was mercilessly slaughtered or forced to leave their homes (muhajirs) and auls were leveled to the ground with Cossacks and Russian colonists settled on the conquered territories.

Despite all of this, official Russian historiography was attempting to create an impression that the Caucasian peoples were "merrily meeting their liberators" from the Russian army. In reality, the local population saw units of the Russian army as the enemy, an aggressor and not as a liberator. The claim that the population of the Caucasus saw these forces armed with cannons - whose officers were sure of their civilizational superiority over the "impoverished wild herds" while the often illiterate soldiers expected mute obedience from the mountaineers - as agents of enlightenment and culture is devoid of any basis.

Nevertheless, the population of the region took an active part in Russia's Caucasian wars. What was the motive for this, what nurtured their fighting attitude?

A certain part of the peoples of the Caucasus, especially from the second half of the XIX century, already perceived the Russian Empire as their homeland, so they took up arms to defend it. Some even tried to demonstrate his loyalty by shedding blood on the battlefield to win the hearts of the imperial authorities. We must also take into account the "natural militancy, the fidelity of the military approach, the desire to improve the conditions of their lives."

In order to immortalize the successful combat operations of the Russian army in the Caucasus, they built a "church of glory" on Golovin Avenue in Tbilisi in 1888 where the militaryhistorical museum was opened. (It is worth noting that after the dissolution of the Soviet Union, other types of memorials became more frequent in the political entities of the North Caucasus. More specifically, the Chechen Republic erected a monument to 46 young girls who were taken hostage when General A. Ermolov burned down one of the auls in 1819. They refused to surrender to the enemy and threw themselves into the Terek River from a high cliff [18]. In Maykop (Karachay-Cherkessia), a monument resembling the Adygean hearth was erected to commemorate the victims of the war in Caucasus [10]. They have also established special days for remembering the victims of the war and so on.). The building had ten steel plates on its wall where the dates of important victories and developments in the Caucasian wars were underlined.

Russia's advance towards the Caucasus (not only in its southern but also the northern part) was somewhat facilitated by Georgia as well which from time to time has been reminded to us in a hostile manner by others; however, they are not taking into account that the Romanov Empire would have accomplished all of this without Georgia as well, albeit later, with more difficulty and greater losses.

In order to gain a foothold in the Caucasus, Tsarist Russia conducted four wars with the Ottoman Empire and two with Iran in the $19^{\text {th }}$ century alone. With these successful wars, it managed to remove both of these adversaries from the Caucasus, becoming dominant in the area that it used to dispute with them. By penetrating the region, Russia gained the status of a Caucasian state. At the same time, an Empire, which for a long time had no access to the sea, became a state of the Black Sea region, gaining an important base of operations for moving towards the Middle East. Russia's positions both domestically as well as on the international arena were significantly strengthened.

Russian history presents success in the wars with the Ottoman Empire as the liberation of the Caucasus while Ottoman history sees this as an injustice and an occupation of these territories by Russia.

For the population of the Caucasus, both of the confronted parties were violent conquerors. As they exchanged roles, one hegemon was replaced by another while the region remained a victim of violence and a colonial periphery.

It is interesting to point out that Russia always managed to maintain conquered territories. It rarely ever lost the land it had conquered. Scholars state that one of the main reasons for this was that political integration was followed by largescale colonization. Historically, Russia had a large population. The government was cleverly using this in integrating new territories. In order to strengthen imperial power and extend a reliable social base, the Tsarist government utilized ethnic expansion in the annexed lands. Clear examples of this include the resettlement of Cossacks on the newly conquered lands of the North Caucasus, settling Armenians from Iran and the Ottoman Empire in the South Caucasus and other migration projects in which the Russian imperial government had a lion's share.

Russia - both Tsarist and contemporary, has been called derzhava [Russian for "power"] for a good reason as it expresses the prowess of the Russian state in terms of political power, its imperial nature and character. This term is so closely intertwined with the Russian reality that the notion of derzhava is considered to be a specialized Russian form of an imperial conquest policy.

Starting from 1801 until the 1990 s, with the exception of 1918-1920, Russia was the factual ruler and governor of the Caucasus. Lengthy military operations conducted for conquering these lands and the suppression of the anticolonial rebellions of the local population took the lives of thousands of Russian soldiers. The Tsarist government also invested solid amounts in creating infrastructure within the region, implementing a number of large-scale projects (railway, the Baku-Batumi pipeline and others). It must also be pointed out that numerous similar actions were done in this regard in the Soviet period as well. In Russia, they carefully count and calculate all of this up until today. On the other hand, they do not care whatsoever about the great casualties among the conquered population as a result of all abovementioned developments. Today, nobody disputes the fact that Tsarist Russia, as well as the Soviet Union, created infrastructure in the peripheries mostly for their own needs. The Tsarist government did not build a railway in Georgia in order to improve service and comfort for the local population 
nor did it build the pipeline for the good of the inhabitants of Georgia. Both of them, above all, were in the interests of the Empire and served its strategic and economic goals. It is also not recognized that a significant part of spending in the Caucasus came from local revenues as they believe that the South Caucasus is a region which is in Russia's vital interests which is why they should not even think about leaving it.

The sturdiness and stability of Russia's derzhava-like aspirations vis-à-vis owning and controlling "vitally important real estate" in the Caucasus are clearly visible in the official statements and claims of Russia's contemporary representatives. "The geopolitical reality of Trans-Caucasia is basically the same that it was in the $19^{\text {th }}$ century. We would not be able to leave the Caucasus now even if we wanted to and it is naïve to call on us to do so. We must not allow the vacuum of security in the South Caucasus to be filled by other foreign states to the detriment to Russian interests," stated the famous Russian public figure, Chairman of Russia's Union of Industry and Enterprises, A. Volski [19]. The President of Russia, Vladimir Putin, stated: "As for Trans-Caucasia, Russia has never entertained leaving it. On the contrary, we intend to strengthen our positions in the region" [37]. Therefore, it is certainly no coincidence that after the 2008 August war between Russia and Georgia, the Kremlin declared the Caucasus region to be a zone of its "special interests."

The political leadership of the Russian Federation is supported by academic circles as well. For example, the former Head of Social and Philosophical Research of the Russian Academy of Sciences, A. Paranin, believes that Eurasia, including the South Caucasus, of course, is the "natural area" of Russia. Russia has historically served as a unifier of this area and instituted civilization there. Therefore, Paranin adds that Russia must maintain this function and take the burden of bringing enlightenment to Eurasia and protecting civil rights there [40].

Russia is not at all willing to forget about its former colony. In 2000, a unique edition was published in Moscow, entitled „Кавказ в сердце России“ [Caucasus in the Heart of Russia], whose foreword was written not by some famous scientist studying the Caucasus but, rather, the Head of the Information Division of the Russian Presidential Administration at the time, Sergey Iasrtzhembski [17]. This fact makes it clear that this book has more of a political purpose rather than a scientific one. The direction of the Caucasus still has an active role in contemporary Russia's geopolitics and geo-strategy. "Our people are rich spiritually and morally, we have grounds for being proud. We have something to love and protect, something to which to aspire. Therefore, we will not back down in the Caucasus," stated the then Russian President, D. Medvedev, in his address to the Russian Federal Assembly on November 5, 2008 [25].

One other factor is also notable: none of the geopolitical concepts created by Russia considers that the Russian strategy towards Georgia is compatible with a unified, strong and stable state there. On the contrary, many do not see a place for Georgia on the world political map at all and, rather, focus on its partition, federalization or as a model of a confederacy while others offer parts of our territories to neighboring states and so on.

It is known that the dissolution of the USSR and the replacement of the bipolar system also upset the geopolitical balance established in the South Caucasus in the $20^{\text {th }}$ century. The region took on the significance of a strategic space located between Europe, Russia and the Middle East [16]. The establishment of the independent states of Georgia, Armenia and Azerbaijan became a prerequisite for the weakening of Moscow's positions there and Russia's eventual departure from the South Caucasus [32].

After the collapse of the Soviet Empire or, as V. Putin called it, the "greatest geopolitical catastrophe" of the $20^{\text {th }}$ century, Russia underwent a heavy ten-15 years of "humiliation." Later, when it strengthened itself economically through its oil dollars, Russia, as the legal successor of the Soviet Union, once again found its imperial ambitions. It finds it difficult to let go of the status of a great power which it believes to be its "genetic part" [15] and does not plan on losing it.

One of the priority directions of Russia's foreign policy today is once again maintaining political, economic and military influence over the South Caucasian republics. In order to camouflage its actual aspirations, the Kremlin presents the new situation and realities in the South Caucasus as if it were threatening Russia's national security and vital interests. This view of the current political leadership of Russia is clearly reflected in various versions of the Russian Foreign Policy Concept adopted after the year 2000.

In the post-Soviet reality, the North Caucasus remained an indispensable part of the Russian Federation while the Kremlin has somewhat diversified its interests in the South Caucasus. Of these interests on the contemporary stage, we can distinguish economic, geopolitical and geo-strategic layers which are backed by specific forces and certain political, military or business circles which act within the framework of a unified state policy rather than independently.

In terms of geopolitics, the effective control of the South Caucasus also provides a significant basis for Russia to maintain stability in the North Caucasus as well. In the cases of conflicts with the rebellious Ingush peoples or the populations of other North Caucasian republics, Moscow needs the South Caucasus, which will be under its influence, to serve as a reliable pillar. At the same time, the Kremlin is also interested in stopping the ethnic-political conflicts in the South Caucasus from spreading to Russian regions as it would pose a serious threat to Russia's territorial integrity. Despite this, the peaceful and stable development of the South Caucasus is not necessarily in Russia's interests. It prefers "controlled instability" and the current status-quo within the region [13].

The economic and communicational value of the South Caucasus is mostly based on local energy resources and the activation of new routes for transporting them. It has been calculated that the Caspian Sea region (the South Caucasus 
and Central Asia) is home to 3-4\% of the overall oil reserves and $4-6 \%$ of the overall natural gas reserves in the world. These numbers do not seem impressive in comparison with the global reserves, yet they are certainly not insignificant. (Russian interests towards Caucasian oil and natural gas is not due to the desire of consuming it. Russia itself is a very large oil and gas exporting state. The European Union member states alone consume $25 \%$ of Russia's energy resources (according to forecasts, this number will increase to $40 \%$ by 2030 ).

The Kremlin knows perfectly well that the oil and gas from the Caspian Sea basin and Central Asia has more importance for the West today and if these resources were to end up in Europe bypassing Russia, Moscow's leverage for influencing Europe will be weakened significantly. This is precisely why the foreign policy vector of the Russian Federation in the South Caucasus is substantially determined by its energy policy as well. Russia aspires to establish control over alternative routes of transportation for Caspian Sea basin energy resources, which pass through Georgia, thereby achieving a factual monopoly in supplying Europe with energy resources.

In parallel, Russia needs to acquire the Georgian part of the Russia-Georgia-Armenia natural gas pipeline so that it can take gas from Iran to the north and supply it to Western Europe all by itself. It is not difficult to deduce that Russia is not attracted to controlling energy routes for no reason at all. Moscow is interested in using the oil and gas policies as weapons with the goal of further strengthening its influence on parts of Western Europe. It is not by accident that Russian experts point out that: "Now, Russia needs the Caucasus more than the Caucasus needs Russia.

Of the Kremlin's economic interests in the Caucasus, we also must not exclude that this region is a good market for Russian products and technologies; apart from energy resources, one must also take into account local raw materials, mines and so on. Russia is one of the top trading partners for both Azerbaijan and Armenia. Its trade turnover with Azerbaijan amounted to USD 3.2 billion in 2019 while the amount of Russian investments there reached USD 4.5 billion [39].

Azerbaijan managed to strike a deal with Russia (Russian military bases left Azerbaijan) and also forge ties with the West. From 1997, an Agreement on Friendship and Cooperation between Russian and Azerbaijan has been in force. Parallel to cooperating and avoiding confrontation with its northern neighbor, Baku is actively seeking ways for integration into Western economic and political structures.

In the South Caucasus, the Russian Federation has the closest ties with Armenia. The Kremlin's strategic tasks in the South Caucasus and the no-less complicated region of Western Asia makes Armenia's role, as Russia's main foothold in this area, ever more important. At the same time, in the Moscow-Tehran geopolitical axis, Yerevan automatically serves as an additional strategic chain connecting Russia with Iran [11].

Moscow and Yerevan are also military-political allies. The Armenian state, unlike Georgia and Azerbaijan, consented to the presence of Russian military units on its territory. Russia's $102^{\text {nd }}$ military base is located in Armenia [38] and at the same time Armenia is the only republic in the South Caucasus that is a member of the Russian-led Collective Security Treaty Organization (ОДКБ) while Georgia and Azerbaijan left this organization in 1999. It is notable that in 2014, the Armenian Parliament also approved the treaty on joining the Eurasian Economic Union [1] and Armenia is also the only South Caucasian state that has full membership in this organization today. This is a reflection of the close coordination with Russia. The Armenian economy has also been largely dependent on Russia for the past two decades. The construction of a pipeline connecting Iran with Armenia is on-going and Russia is the largest shareholder there as well. Russia also has concessions on the Armenian railways, is modernizing numerous Armenian industries and so on. In 2018, around 54\% of direct investments to Armenia came from Russia [30]. Despite all of this, Yerevan is still trying to not limit itself with Russia alone and avoid distancing itself from the West completely.

As for Russia's relations with Georgia, it can be said that it was going in a tense and difficult manner all throughout the post-Soviet period. Both countries saw several changes in the top leadership of the state yet changing presidents did not help in settling relations between the two. In 1994, B. Yeltsin and E. Shevardnadze reached an understanding based on which the two leaders signed the Agreement on Friendship, Good Neighborly Relations and Cooperation between the Republic of Georgia and Russian Federation; however, this document has not been ratified by the Russian Duma to date. For Russia it is unacceptable to have a free, sovereign and unified Georgian state in its former area of influence, especially if the latter has a clear Western orientation.

The active involvement of Tbilisi in international projects regarding the transportation of Caspian energy resources through Georgia, beginning the removal of Russian military bases from Georgia in accordance with the 1999 Istanbul Summit of the Council of Europe, the formation of the GUAM (is an international organization created in 1997 which brings together Georgia, Ukraine, Azerbaijan and Moldova (Uzbekistan was also part of it from 1999 to 2005) with Georgia's participation, approximation with the United States and attempts of integrating Georgia into the North Atlantic Treaty Organization, were steps taken by our country in accordance with its national interests. Moscow, however, saw them as actions in opposition to Russia. The Kremlin formed its own puppet regimes in Abkhazia and the Tskhinvali region which it then unilaterally declared as independent states after the 2008 August war in line with its orientation of disintegrating Georgia. By creating military bases in Sokhumi and Tskhinvali, Russia strengthened its influence on the occupied Georgian regions. It exercises the policy of borderization in brazen defiance of international law - erecting artificial barriers, installing border signs, fences and barbed wire, aspiring to widening the occupation line, also causing the escalation of tensions in the process. At the same time, Russian propagandist sources use various 
types of manipulation through soft power and are attempting to stoke anti-Western sentiments in the population of Georgia. Currently, the two states have completely severed diplomatic ties and the situation remains tense.

After the dissolution of the Soviet Union, the South Caucasus also ended up in the sphere of the serious interests of Turkey, Iran, China and Western Europe, not as "a problematic place but as a potential region" [32]. For example, Chinese and Azerbaijani companies signed ten agreements covering various areas on the sidelines of the second Belt and Road Forum for International Cooperation held in Beijing in April 2019. The total amount of contracts is \$ 821 million [6]. At the same time, a strong political actor - the United States of America appeared there as well. With the will and financial support of US state structures, well-known trans-Caucasian oil and gas pipelines started functioning. As S. Markedonov and M. Suchkov write, the US attitude has gone beyond "get-to-know-the region" phase and developed into a building partnerships [24]. Today, developments in the South Caucasus and around it are no longer measured through regional frameworks and have, rather, become indispensable parts of global processes. It is no coincidence that the West is actively opposing Russia's actions in the region. (The Rose and Orange Revolutions that took place in Georgia and Ukraine cause increasing concern in Russia as the Kremlin believes that these revolutions were activities directed by the West to constrain Russia and destabilize it domestically. The countersteps taken by the Russian Federation were clearly excessive as it started a war with Georgia and annexed Crimea). Apart from the United States and NATO, the European Union has also recently become highly interested in the South Caucasus. The EU's famous European Neighborhood Policy is sufficient for making this clear in which all three states of the region have been involved since 2004 and numerous European projects are being successfully implemented throughout the region to date. Among the states in the region, Georgia thus far maintains leadership in terms of its good relations with the European Union (Georgia has been a member of the Council of Europe since 1999. Armenia and Azerbaijan joined it in 2001). Returning to the European family is Georgia's clearly stated goal which has also been reflected in its constitution. If Georgia achieves its desired goal of European integration in the nearest future, it is entirely possible that Armenia and Azerbaijan will have an alternative to Russia in the form of the West (with its values, institutions and so on). For its part, the United States will also have to fight against Russia's dominance in the Caucasus, but Washington must coordinate its efforts with the EU [29].

\section{Conclusions}

The study showed that the Caucasus region had turned to Russian interests after the fall of the Byzantine Empire. In the XVI-XVII centuries, the main motives for Russia's expansion in the Caucasus were determined by strategic tasks. Also, the geopolitical factor, the trade and transit function of the Caucasus, the political, military and economic importance of the region for Russia were taken into account.

Russia actively intervened in the ongoing Iran-Ottoman conflict in the Caucasus, managed to oust both of them from here, and dominated the region alone. From 1801 onwards, except for 1918-1920, until the 1990s, Russia was the defacto owner of the Caucasus.

Russian historiography (both Soviet and modern) presents the Russian Empire as the liberator of the Caucasus, and a large part of the local population saw and still sees the abuser, the invader in Russia.

After the collapse of the Soviet Union, the North Caucasus remained an integral part of the Russian Federation, and the independent republics of Georgia, Armenia, and Azerbaijan were formed in the south. Nevertheless, Russia is not going to leave the South Caucasus, moreover, it is trying to strengthen its positions and maintain its political, economic or military influence over these republics.

The present letter was completed when the AzerbaijanArmenia armed conflict in the South Caucasus region was observed. The Kremlin's mediation in the war and the deployment of Russian peacekeepers in Nagorno-Karabakh after the ceasefire, as well as the intensification of Turkey's position in the region, may lead to some geopolitical changes, which are the subject of a separate discussion.

\section{References}

[1] Aleksanyan, G. (2016). The military-political aspect of Russian policy in the Transcaucasus at the present stage, p. 17 [In Russian]. Retrieved 25 November 2020. https://cyberleninka.ru/article/n/voennopoliticheskiy-aspektrossiyskoy-politiki-v-zakavkazie-na-sovremennometape/viewer.

[2] Anisimov, E. (1999). Historical roots of imperial thinking in Russia [In Russian]. Retrieved 19 November 2020. http://srch.slav.hokudai.ac.jp/sympo/Proceed97/Anisimov.html.

[3] Berdzenishvili, N. Issues of Georgian History] V, Tbilisi, 1971, p. 236 [In Georgian].

[4] Bocharnikov, I. Caucasian policy of Russia in the X-XX centuries, M., 2013, p. 39 [In Russian]. Retrieved 27 November 2020. http://russian7.ru/post/zachem-rossiyskayaimperiya-zavoevala-k/.

[5] Bocharnikov, I. (2014). Caucasus in the history of Russia. The origins of Russia's interests in the Caucasus [In Russian]. Retrieved $29 \quad$ November 2020. http://nicpnb.ru/articles/kavkaz-v-istorii-rossii-istoki-interesov-rossiina-kavkaze/.

[6] China, Azerbaijan sign deals worth \$821M (2019). Retrieved $30 \quad$ November 2020. https://www.chinadaily.com.cn/a/201904/25/WS5cc15b33a31 04842260b8595.html.

[7] Gordin, J. (2014). Caucasian Atlantis. 300 years of war [In Russian]. Retrieved $29 \quad$ November 2020. http://www.rulit.me/books/kavkazskaya-atlantida-300-letvojny-read-280530-6.html. 
[8] Gordin, J. Caucasus: earth and blood, SPb., 2000, p. 44 [In Russian]. $\quad$ Retrieved $29 \quad$ November 2020http://www.globalaffairs.ru/number/n_5977.

[9] Dubrovin, N. History of the war and the rule of Russians in the Caucasus, vol. 1, book 1. SPb., 1871, p. 14 [In Russian].

[10] Day of Remembrance and Mourning for the Victims of the Caucasian War will be celebrated in the KCR (2009). Retrieved $10 \quad$ December 2020 https://ria.ru/20090521/171771513.html.

[11] Dugin, A. (2002). Fundamentals of Geopolitics [In Russian]. Retrieved $14 \quad$ December 2020. http://www.geopolitika.ru/geop4-7.htm.

[12] Fadeev, R. Sixty years of the Caucasian War. Tiflis, 1860, p. 12-13 [In Russian].

[13] Hedenskog, J. (2018). Holmquist E. and Norberg, J. Security in the Caucasus Russian Policy and Military Posture, p. 4.

[14] Janelidze, O. Writings on the History of Georgian-Russian Relations. Tbilisi, 2013, pp. 110-111 [In Georgian].

[15] Jonavicius, L. Delcour, L. Dragneva, R. and Wolczuk K. (2019). Russian Interests, Strategies and Instruments in the Common Neighbourhood, p. 8. Retrieved 11 December 2020. http://eu-strat.eu/wp-content/uploads/2019/03/EU-STRATWorking-Paper-No.-16.pdf.

[16] Jim van Moorsel, (2017). Economic and geopolitical partnership in the Caucasus: The Azerbaijani-GeorgianTurkish approach. Retrieved 14 December 2020. http://regional-dialogue.com/en/economic-and-geopoliticalpartnership-in-the-caucasus-the-azerbaijani-georgian-turkishapproach $\% \mathrm{E} 1 \% 83 \% 90 /$.

[17] Caucasus in the heart of Russia, M, 2000. [In Russian].

[18] R. Kadyrov opened a monument to women - heroes of the war with Russia (2013). https://www.rbc.ru/society/16/09/2013/57040f929a794761c0c e1c98.

[19] Katelevsky A. (2012). Strategic interests and policy of Russia in the Caucasus. Retrieved 28 November 2020. https://superinf.ru/view_helpstud.php?id=2504.

[20] Kovalevsky, P. Conquest of the Caucasus by Russia. Historical sketches Russian archive, St. Petersburg, 1896, p. 334 [In Russian].

[21] Kornilov, A. Course of the history of Russia in the XIX century, M., 1993, p. 21 [In Russian].

[22] Kostomarov, N. Russian history in the biographies of its main figures, M., 2004, p. 189 [In Russian].

[23] Lisitsina, G. Caucasian Committee - the highest state institution for the administration of the Caucasus (1845 1882), in the book - Russia and the Caucasus: through two centuries, St. Petersburg., 2001, p. 154 [In Russian].

[24] Markedonov, S. Suchkov, M. (2020). Retrieved 11 December 2020. Russia and the United States in the Caucasus: cooperation and competition. https://mgimo.ru/upload/iblock/dbc/Russia\%20and\%20the $\% 2$ 0United\%20States\%20in\%20the\%20Caucasus\%20(2020).pdf.

[25] Presidential Address to the Federal Assembly (2008). $\begin{array}{llll}\text { Retrieved } & 23 & \text { November } & 2020 .\end{array}$ http://www.regnum.ru/news/1079115.html.

[26] Potto, V. Caucasian War: In 5 volumes, Stavropol, 1994, vol. 1, p. 14 [In Russian].

[27] Rosen, A. Notes of the Decembrist, Irkutsk, 1984, p. 389-390 [In Russian].

[28] Romanov, P. (2015). The barren vine of the Georgievsky treatise. Retrieved 13 December 2020 http://www.aif.ru/society/opinion/besplodnaya_loza_georgievs kogo_traktata.

[29] Rumer, E. Sokolsky, R. Stronski, P. (2020). U.S. Policy Toward the South Caucasus: Take Three. Retrieved 15 December 2020. https://carnegieendowment.org/2017/05/31/u.s.-policytoward-south-caucasus-take-three-pub-70122.

[30] Russia provides more than half of net direct investment in Armenia - trade representative (2019). Retrieved 9 December 2020. https://newsarmenia.am/news/economy/rossiyaobespechivaet-bolee-poloviny-chistykh-pryamykh-investitsiyv-armeniyu-torgpred/.

[31] Russia: A Special Imperial Way? (2005). Retrieved 15 December 2020. https://globalaffairs.ru/articles/rossiyaosobyj-imperskij-put/

[32] Svante E. Cornell, Azerbaijan Since Independence. New York, 2011, p. 342.

[33] Soldatov, S. Caucasian War of 1817-1864 in the Assessment of Contemporaries, topic of dissertation and abstract, Chelyabinsk, 2004. Retrieved 9 December 2020. https://www.dissercat.com/content/kavkazskaya-voina-18171864-godov-v- otsenke-sovremennikov.

[34] Sotnichenko, I. North Caucasus in the sphere of political influence of the Ottoman Empire in the XIX - early XX centuries, dissertation for the degree of candidate of historical sciences, St. Petersburg, 2011, p. 5 [In Russian].

[35] Soloviev, Y. Autocracy and nobility at the end of the XIX century. L., 1973, p. 195 [In Russian].

[36] Shatokhina, L. (2000). Russian Policy in the North-West Caucasus in the 20-60s of the XIX century. Thesis topic and abstract, M., 2000. Retrieved 9 December 2020. https://www.dissercat.com/content/politika-rossii-na-severozapadnom-kavkaze-v-20-60-e-gody-xix-veka.

[37] Speech at the Russian-Armenian Interregional Forum (2013). $\begin{array}{llll}\text { Retrieved } & 12 & \text { December } & 2020 .\end{array}$ http://kremlin.ru/events/president/transcripts/19733

[38] The Armenian parliament left the Russian military base in Gyumri for another 33 years (2011). Retrieved 11 December 2020. https://lenta.ru/news/2011/04/12/baza/.

[39] May Republic Day in Azerbaijan (2020). Retrieved 10 December 2020. https://www.instagram.com/p/CAuuMa3HqBF/?utm_source=i g_embed.

[40] Urushadze, E. Russian Foreign Policy Thought in the PostSoviet Period. Tbilisi, 2006, p. 28 [In Georgian].

[41] Why the Russian Empire conquered the Caucasus (2017). Retrieved 7 December 2020. http://russian7.ru/post/zachemrossiyskaya-imperiya-zavoevala-k/. 